\title{
ARTIGO - JOGOS COMO RECURSOS DIDÁTICOS NA ALFABETIZAC̣ÃO: 0 QUE DIZEM E FAZEM AS PROFESSORAS
}

LIANE CASTRO DE ARAUJO'

ORCID: https://orcid.org/0000-0002-7807-1218

I Universidade Federal da Bahia, Faculdade de Educação, Salvador, BA, Brasil.

Liane C. de Araujo - Doutora em Educação pela Universidade Federal da Bahia (UFBA). Professora e pesquisadora da Faculdade de Educação (FACED) - Grupo de Estudo e Pesquisa em Educação e Linguagem (GELING). E-mail: <lica@ufba.br $>$.

RESUMO: $\mathrm{O}$ artigo apresenta resultados parciais de uma pesquisa que visa a investigar práticas alfabetizadoras que circulam em escolas da rede municipal de Salvador quanto ao uso de jogos voltados à apropriação da língua escrita. A metodologia qualitativa, de perspectiva colaborativa, propõe o levantamento de acervos, práticas e discursos envolvendo jogos e outros materiais para a alfabetização, bem como uma intervenção junto a escolas, visando a construir conhecimentos partilhados sobre esses recursos, articulando função lúdica e função didática. Resultados da primeira fase da pesquisa, a partir de entrevistas e observação, revelam que as professoras reconhecem o valor dos jogos na alfabetização, mas sua baixa frequência nas rotinas e no planejamento indica que esse uso é incipiente, sendo muitas as justificativas dadas para essa ausência. Os resultados sugerem que é preciso investir, na formação docente, em ações para fortalecer estratégias didáticas que abordam o ensino da escrita de modo reflexivo, não mecânico.

Palavras-chave: Alfabetização. Jogos. Recursos didáticos.

\section{GAMES AS DIDACTIC RESOURCES IN EARLY LITERACY: WHAT TEACHERS SAY AND DO}

ABSTRACT: This article presents partial results of an ongoing research, with the objective of investigating early literacy practices in schools of the municipal education system of Salvador, regarding the use of games as didactic resources aimed at appropriation of written language. The qualitative methodology, from a collaborative perspective, proposes the collection of repositories, practices and discourses involving games and materials for early literacy, as well as an intervention in schools, with the purpose of constructing shared knowledge about these resources, articulating playful function and pedagogical function. Results from the 
first phase of the research, composed from interviews and observation, reveal that teachers recognize the value of games in early literacy, but their low frequency in routines and planning indicates that this use is incipient, with many justifications given for this absence. The research suggest thatit is necessary to invest, in the training of teachers, in actions to strengthen didactic strategies that approach the teaching of written language in a reflexive, non-mechanical way.

Keywords: Early literacy. Games. Didatic resources.

\section{INTRODUĈ̣̃O}

Nas últimas quatro décadas, o campo da alfabetização se transformou muito na instância das teorizações, em função de contribuições produzidas em área diversas do conhecimento, questionando-se os métodos tradicionais aplicados até então, de base associacionista e mecanicista. Novas concepções de língua e linguagem, de aprendizagem e de ensino, bem como do sujeito que aprende, foram decisivas para engendrar mudanças nas concepções de alfabetização, que passam a considerar a escrita não como um código de transcrição da fala, mas como prática sociocultural que envolve um sistema complexo de notação da língua falada, de base alfabética, e a aprendizagem de suas propriedades e funcionamento como uma apropriação ativa pelos sujeitos nas interações sociais.

No entanto, a despeito de tal panorama no campo teórico, estudos têm demonstrado que, na instância das práticas alfabetizadoras, encontramos ora a manutenção de estratégias didáticas tradicionais no ensino da notação da língua - geralmente mescladas ou justapostas às situações de letramento -, ora certa negligência com o ensino sistemático do funcionamento da escrita alfabética (GONTIJO, 2014; MORTAT'TI, 2010). Nesse último caso, essa negligência pode refletir perspectivas - construtivistas e/ou sociointeracionistas - que não enfatizam esse ensino explícito, e que, hegemônicas no discurso pedagógico, operaram certo silenciamento de outras tantas perspectivas.

O foco no processo psicogenético da apropriação da escrita e nos aspectos socioculturais do letramento, embora implique avanços fundamentais no campo da alfabetização, minimizou a ênfase em sua faceta propriamente linguística (SOARES, 2016), que tem, no entanto, sua especificidade e precisa ser considerada - ao que Magda Soares (2003) nomeou de "reinvenção da alfabetização". Gontijo (2014), no entanto, apresenta e discute um conjunto de pesquisas que indicam 
que, no campo das concretizações, se verifica, frequentemente, ao contrário, uma continuidade de práticas mecânicas tradicionais de ensino da notação alfabética, mesmo que ao lado ou a partir de textos. Assim, na dinâmica das mudanças e continuidades que operam, simultaneamente, no modo de se conceber a alfabetização - como discute Mortatti (2000) - a "desinvenção da alfabetização" se deu, em grande medida, apenas no âmbito do discurso educacional.

O conhecimento metalinguístico na alfabetização, em especial a consciência fonológica, bem como o processamento da leitura, são aspectos abordados pela psicologia cognitiva da leitura que, ressignificados no âmbito de um entendimento mais amplo da apropriação da linguagem escrita, podem contribuir com o campo didático se, no discurso pedagógico, pudermos sair das polarizações instaladas com concepções em conflito, em especial a perspectiva construtivista e a abordagem fônica. Os estudos sobre a consciência fonológica têm força didática, como ressalta Piccoli (2015), podendo contribuir para constituir metodologias de alfabetização que investem, sistematicamente, no ensino do funcionamento do sistema de escrita, sem necessariamente desdobrar-se em um método fônico, sintético e mecânico. Afinal, refletir sobre as partes sonoras das palavras e sua representação gráfica é fundamental num sistema que nota, em alguma medida, a língua falada (cf. GOMBERT, 1990; MORAIS, 2006, 2012).

Uma perspectiva mais conciliadora, que assinala a importância do ensino das propriedades do sistema e seu funcionamento alfabético, de forma explícita, no contexto das práticas letradas, como a de Soares (2016), Morais, Albuquerque e Leal (2005) e Morais (2012), ainda carece de desdobramentos efetivos nas práticas e na instância das políticas públicas de alfabetização. ${ }^{1}$ É preciso que, na formação docente, inicial e continuada, se invista, efetivamente, em ações que articulem as facetas sociocultural, interativa e linguística, conforme discutido por Soares (2016), e sejam mobilizados, de forma mais efetiva, os conhecimentos didáticos e as metodologias produtivas para abordar a notação da língua e sua base fonológica, de forma sistemática e não casual, e tampouco de forma mecânica como nos antigos métodos, questionados a partir dos anos 1980.

É nesse panorama que se insere a discussão sobre jogos como um recurso didático potente para a alfabetização, partindose do princípio de que, além de se constituírem em uma prática sociocultural que envolve o lúdico, também podem ter um papel na aprendizagem. Assim, assumindo a faceta linguística do ensino da língua escrita como foco de preocupação e os recursos didáticos 
como a materialização da ação docente e não como acessórios dessa ação, conforme discutem Silva e Morais (2011), uma pesquisa, intitulada "Jogos e materiais pedagógicos na alfabetização", está em andamento na Faculdade de Educação da Universidade Federal da Bahia (FACED/UFBA), visando a investigar sobre o uso de jogos e de materiais semelhantes, estruturados como recursos didáticos para a alfabetização, em escolas da rede municipal de ensino de Salvador. ${ }^{2}$

O presente artigo visa a apresentar dados parciais da pesquisa, que tem como escopo maior discutir sobre a dimensão material da ação e da formação de professores, articulando ação docente nas escolas públicas (dos 4 anos da Educação Infantil ao $3^{\circ}$ ano do Ensino Fundamental) e a formação inicial na Universidade. A pesquisa, de caráter qualitativo e natureza colaborativa (IPIAPINA, 2008; BORTONI-RICARDO, 2008), tem como objetivo geral identificar, analisar, mobilizar e divulgar práticas alfabetizadoras e materiais didático-pedagógicos nos processos de ensino e aprendizagem da língua escrita. Conta com uma fase inicial de levantamento de dados em escolas da rede municipal de Salvador, quanto a seus acervos de jogos e materiais estruturados, e quanto aos discursos e às práticas envolvendo recursos didáticos para a alfabetização. Após esse levantamento, na fase de intervenção, propõe-se, em algumas turmas, situações didáticas com uso de jogos de linguagem e materiais confeccionados a partir do repertório da tradição oral - situações essas planejadas e desenvolvidas colaborativamente com as professoras regentes. ${ }^{3} \mathrm{~A}$ constituição de um Laboratório de Acervos Pedagógicos (LAP) na Faculdade de Educação da UFBA, como espaço permanente de pesquisa, mobilização, produção, validação e divulgação de acervos e de estratégias didáticas a eles articuladas, configura-se como processo e como produto da pesquisa. ${ }^{4}$ É no contexto do LAP que, visando à intervenção - planejamento conjunto, intervenção e avaliação da intervenção - as pesquisadoras, bolsistas e voluntárias da pesquisa, ${ }^{5}$ têm participado de oficinas de produção, nas quais, além da confecção dos materiais, são discutidos os fundamentos e princípios didáticos envolvendo esses recursos na alfabetização. ${ }^{6}$

O artigo aborda a primeira etapa da pesquisa no ciclo da alfabetização ( $1^{\circ}$ a $3^{\circ}$ anos), apresentando resultados parciais e análises referentes ao levantamento de dados quanto aos discursos e às práticas que circulam nas escolas envolvendo os usos de jogos na alfabetização. Essa etapa, realizada entre 2017 e 2019, é relevante em uma pesquisa de natureza colaborativa, com ações de intervenção, na medida em que é fundamental ouvir as professoras, observar como as práticas de alfabetização têm se concretizado e compreender a rede 
de discursos que se tece em torno dessa problemática. Os objetivos específicos dessa fase de levantamento de dados, sem perder de vista a natureza colaborativa da pesquisa, referem-se a construir conhecimentos partilhados sobre o uso de jogos no planejamento docente e nas práticas alfabetizadoras da rede de Salvador. ${ }^{7}$

Os resultados apresentados e discutidos abrangem 7 escolas, situadas no centro de Salvador, 25 professoras de $1^{\circ}$ ao $3^{\circ}$ anos, e 6 coordenadoras pedagógicas. Os dispositivos metodológicos adotados para obter os dados quanto aos discursos e as práticas das professoras foram a entrevista semiestruturada e a observação de algumas salas de aula, desenvolvidas por três bolsistas. ${ }^{8}$ Os dados estão sendo categorizados e analisados interpretativamente, a partir de princípios e procedimentos da pesquisa qualitativa (SZYMANSKI, 2002; LÜDKE e ANDRÉ, 2017; BORTONI-RICARDO, 2008), cruzandose discursos, práticas e o levantamento dos acervos presentes nas escolas, bem como depoimentos das coordenadoras pedagógicas sobre os acervos e seu uso pelas docentes. Convém sublinhar que, nas entrevistas, considerou-se não apenas as linhas do dito, mas as entrelinhas do dizer, sendo relevante a forma de dizê-lo e a coesão com o todo do depoimento de cada professora. ${ }^{?}$

Para analisar e discutir os resultados parciais da etapa da pesquisa aqui delineada, quanto ao que dizem e fazem as professoras, sujeitos da pesquisa, inicialmente abordaremos a discussão sobre os jogos na alfabetização e, em seguida, serão apresentados os resultados e sua análise de forma articulada.

\section{OS JOGOS DE LINGUAGEM NA ALFABETIZAÇÃO}

A função primordial da linguagem é, evidentemente, a interlocução. Entretanto, além da função comunicativa, podemos assumir diante dela uma atitude metacognitiva, metalinguística, tomando-a, também, como objeto de análise, foco de atenção deliberada. (GOMBERT, 1990) A consciência fonológica, tipo de atividade metalinguística referente à capacidade de segmentar, analisar e manipular, intencionalmente, diversas unidades sonoras da língua falada, e a apropriação do princípio alfabético, que articula as unidades fonêmicas aos grafemas na escrita, são fundamentais na alfabetização, conforme inúmeras pesquisas citadas em Snowling e Hulme (2013), Gombert (1990), Cardoso-Martins (1991), dentre outros. No campo da educação, Soares (2016) e Morais (2012) chamam a atenção para a necessária abordagem desses aspectos ao lado das práticas sociais de leitura e escrita. 
É importante sublinhar que a assunção do papel do ensino sistemático e explícito da notação da língua, de base fonológica, não é exclusividade do método fônico nem da psicologia cognitiva da leitura em geral. Uma perspectiva que conta com a aprendizagem incidental do funcionamento alfabético da escrita, sob o pressuposto de que a criança seria capaz de "[...] descobrir por si mesma as relações fonema-grafema, em sua interação com material escrito e por meio de experiências com práticas de leitura e de escrita" (cf. SOARES, 2004, p. 14) contribui para acirrar esse antagonismo com o método fônico, conforme apontado por Morais (2006) e Soares (2004). ${ }^{10} \mathrm{O}$ ensino da língua escrita exige estratégias didático-pedagógicas diversificadas para atender aos diversos objetivos de aprendizagem no âmbito de todas as suas facetas, inclusive a faceta linguística, com seus aspectos fonológicos e notacionais.

Como apontado por alguns autores, tais que Morais (2012), Leal, Albuquerque e Leite (2005) e Araujo (2017, 2018), os jogos de linguagem podem, justamente, constituir estratégias produtivas para provocar a reflexão fonológica envolvendo diversas unidades sonoras, como rimas, sílabas, unidades intrassilábicas e fonemas; para provocar o reconhecimento de palavras, unindo níveis lexicais e sublexicais da leitura; para refletir sobre as propriedades e a lógica de funcionamento alfabético e ortográfico do sistema - aspectos que ora são negligenciados, tratados de forma casual, ora de forma mecânica. Estruturados para abordar determinados conteúdos linguísticos, os jogos demandam que os jogadores elaborem estratégias e busquem vencer desafios, interagindo em função dos objetivos a alcançar no jogo. Brandão et al. (2009, p. 13-14) ratificam: "nos momentos de jogo, as crianças mobilizam saberes acerca da lógica de funcionamento da escrita, consolidando aprendizagens já realizadas ou se apropriando de novos conhecimentos nessa área”.

Esses jogos, no entanto, valem se articulados à ação docente planejada, intencional, na qual o(a) professor(a)escolhe o recurso que melhor se aplica ao conteúdo a ser aprendido e organiza as estratégias didáticas e as formas de mediação que, efetivamente, vão poder ajudar os(as) alunos(as) a compreenderem os princípios da notação da língua. É isso que faz com que os jogos se constituam como um recurso didático e não apenas um material lúdico, motivador.

Ainda que no campo de estudos sobre jogos, as relações entre jogo, educação e a dimensão lúdica sejam marcadas por tensões, não podemos deixar de sinalizar sua potência em relação à aprendizagem, conforme discutem diversos autores. Kishimoto (2003, p. 37-38) lembra que o jogo “[...] potencializa a exploração e 
a construção do conhecimento, pois conta com a motivação interna, típica do lúdico". Não entraremos aqui na vasta bibliografia que define tipologias de jogos, associadas ao desenvolvimento intelectual em geral. Considerando os propósitos da pesquisa ora apresentada, destacaremos, dentre as modalidades de jogo citadas por Kishimoto (2003), o jogo educativo, relacionado à aprendizagem, e em especial, o jogo de regras explícitas - referido, dentre outros autores, tanto por Piaget $(1975,1978)$ quanto por Vigotsky (1984), apesar de suas perspectivas diferentes. O jogo de regras é um tipo de jogo que tem caráter eminentemente social e começa a se manifestar por volta dos quatro, cinco anos, se desenvolvendo, particularmente, a partir dos seis, sete. Sem perder a perspectiva cultural do jogo, destacamos ainda, nesse contexto de discussões, os jogos didáticos, que, conforme Kishimoto (2003), visam ao ensino de objetos de conhecimento específicos. Esses podem permanecer como um tipo de jogo educativo, com a função lúdica preservada, ou podem, comprometê-la. ${ }^{11}$ Para que o jogo didático se configure como jogo de fato, mantendo características que o associem ao lúdico e, ao mesmo tempo, assegure as aprendizagens visadas, é preciso considerar, segundo a autora, o equilíbrio entre as funções lúdica e didática. Piaget já dizia que "os jogos são brincadeiras e ao mesmo tempo meios de aprendizagem” (PIAGET, 1978, p. 87), e para Macedo, Petty e Passos (2000, p. 14), jogar é uma das possibilidades do brincar, "o brincar em um contexto de regras e com um objetivo predefinido". Dohme (2008) expõe uma perspectiva interessante quanto a essa questão do lúdico/didático, afirmando que, para as crianças, ainda que cientes do contexto de ensino, o jogo constitui um fim (ou pode se constituir, dependendo de como é conduzido), sendo o foco, nesse caso, a função lúdica, enquanto para os docentes, o jogo é um meio para alcançar um objetivo relacionado à aprendizagem.

O jogo educativo de regras a que se refere nesse trabalho, portanto, é aquele em que há regras explícitas, jogo de "combinações intelectuais” (PIAGET, 1975, p. 185), visando a um objetivo didático, relacionado a conteúdos específicos, no caso, os aspectos linguísticos fonológicos e/ou notacionais - da escrita, mas sem perder sua potência de jogo. Piaget (1969/1976, p. 158-159) sinaliza que "[...] em todo lugar onde se consegue transformar em jogo a iniciação à leitura, ao cálculo, ou à ortografia, observa-se que as crianças se apaixonam por essas ocupações comumente tidas como maçantes”. Apesar disso e, embora na área da matemática seu uso tenha maior divulgação nas práticas escolares, no campo do ensino e da aprendizagem da língua escrita, 
os estudos sobre jogos e sua concepção como estratégia didática são mais recentes, em geral relacionados a concepções de alfabetização engendradas a partir dos anos 1980. Materiais como alfabetos móveis, jogos de vogais, silabários, embora presentes no mercado há mais tempo, filiavam-se, geralmente, a proposições mais tradicionais de alfabetização. O Programa de formação de professores alfabetizadores (PROFA), ${ }^{12}$ embora não tenha se ocupado de jogos que abordam aspectos sublexicais da apropriação da língua escrita, apresentou, no início dos anos 2000, uma nova perspectiva e usos mais produtivos em relação a materiais como o alfabeto móvel, o crachá, a lista de palavras, dentre outros, condizentes com a didática construtivista que propunha.

A discussão sobre jogos na alfabetização se tornou mais substantiva no Brasil a partir dos anos 2000, no âmbito de concepções de alfabetização mais conciliadoras, que afirmam a importância de, ao lado dos aspectos referentes à cultura escrita, abordar explicitamente o funcionamento do sistema de escrita alfabética (SEA), e que trazem jogos como estratégia produtiva nesse sentido (BRANDÃO et al., 2009; LEAL, ALBUQUERQUE e LEITE, 2005; MORAIS, 2012).

Com o Pró-letramento - programa de formação continuada de professores assumido pela Secretaria de Educação Básica (SEB)/MEC, entre 2005 e 2012 - propostas de uso de jogos para a alfabetização apareceram de modo mais contundente nas políticas públicas. ${ }^{13}$ Paralelamente, um conjunto de jogos destinados à alfabetização foi produzido pelo Centro de Estudos em Educação e Linguagem (CEEL/UFPE) - centro que vem investindo no estudo desses recursos didáticos. A partir de 2013, em parceria com o Ministério da Educação (MEC), a caixa de dez jogos do CEEL foi distribuída às redes que aderiram ao Pacto Nacional de Alfabetização na Idade Certa (PNAIC), ampliando essa perspectiva. ${ }^{14}$ Jogos fonológicos - que antes apareciam mais no campo da fonoaudiologia ou em propostas fônicas de outros países - passaram a circular mais amplamente nas escolas do Brasil, divulgados como recursos produtivos para o ensino da escrita, e validados pela perspectiva de alfabetização em contexto de letramento.

Pesquisas têm sido desenvolvidas sobre o uso de jogos na alfabetização, especialmente, mas não exclusivamente, quanto aos jogos do CEEL/UFPE, como as de Bezerra (2008) e Pessoa, Lino e Silva (2015). É nesse contexto de preocupações que a pesquisa ora apresentada se insere, investigando não apenas os jogos e materiais que circulam nas escolas e os discursos e práticas em torno deles, como também propondo novos jogos e materiais, a partir de um acervo que 
vem se constituindo há mais de 15 anos e que, atualmente, é parte dos materiais do LAP, envolvidos em ações de ensino, pesquisa, extensão na Faculdade de Educação da UFBA. ${ }^{15}$

\section{O QUE DIZEM E FAZEM AS PROFESSORAS}

Uma breve contextualização quanto às políticas de alfabetização na rede municipal de Salvador é condição para se compreender a complexidade que envolve as produções discursivas das docentes, pois essas produções precisam ser analisadas e consideradas à luz do contexto social e histórico em que se inserem. Situações peculiares marcaram o início e a descontinuidade do PNAIC em Salvador, diante da política municipal, envolvendo a compra e a imposição de pacote educacional privado, após adesão ao PNAIC em gestão anterior. A Secretaria Municipal de Educação (SMED) anunciou, em 2013, concomitante ao início da formação do PNAIC, o polêmico lançamento do Programa Alfa e Beto, de perspectiva fônica, sob argumento da necessidade de um sistema de ensino estruturado para sanar os supostos baixos índices de alfabetização no município, revestindo a racionalidade técnica com o discurso de "novidade pedagógica", conforme relata Souza (2018). A imposição autoritária, com o caráter obrigatório, desconsiderou a trajetória de construção pedagógica das escolas e o programa nacional. A resistência de parte da comunidade escolar quanto à não compatibilidade em relação às diretrizes pedagógicas do governo federal (dentre outros aspectos) e à trajetória da própria rede, resultaram na mudança do caráter de imposição para adesão e, assim, algumas escolas terminaram por assumir os materiais e as ações propostas pelo Alfa e Beto e a maioria seguiu com a formação do PNAIC. No entanto, após um ano de PNAIC, no início de 2014, duas das três instituições formadoras na Bahia, inclusive a UFBA, foram desligadas do Programa, de forma escusa, e, após um tempo, o programa foi progressivamente descontinuado em Salvador. Em 2015, a prefeitura anunciou o programa Nossa Rede, cujo material do ciclo de alfabetização foi elaborado pelo Instituto Chapada de Educação e Pesquisa (ICEP/ $\mathrm{BA}$ ), de perspectiva construtivista diametralmente oposta ao Alfa e Beto, e sem a perspectiva mais conciliadora do PNAIC em termos da abordagem mais explícita da faceta linguística. Esse é um contexto relevante para a discussão dos dados da pesquisa.

Os resultados apresentados a seguir advêm de dados obtidos a partir da categorização e análise cruzada e interpretativa das 
entrevistas, validadas, em certos trechos, pelas falas das próprias professoras, conforme a perspectiva hermenêutica discutida em Szymanski (2002). A análise dos dados incluiu a produção de unidades de significados, a organização em categorias, a descrição consistente e o cruzamento dos dados com outros elementos, visando às sínteses, que envolvem a descrição de significados que emergiram dos relatos nas entrevistas e a sua interpretação.

As professoras entrevistadas, em geral, concebem a linguagem escrita como um objeto complexo e apontam tanto aspectos socioculturais ligados ao letramento, quanto os aspectos linguísticos, relativos à apropriação da escrita alfabética e ortográfica. Referemse também à necessidade de conhecer a turma, o nível de leitura e escrita, para planejar o ensino. Entretanto, embora nos discursos, bem como nas práticas de uma das duas professoras observadas, tenham aparecido algumas situações contextualizadas e dinâmicas de apropriação da notação da língua, a abordagem do sistema de escrita, ainda é marcada, fortemente, por características mais tradicionais, envolvendo ensino de letras e sílabas descontextualizadas, ainda que as entrevistadas não assumam defender práticas exaustivas de repetição e memorização. $E$ isso acontece mesmo quando a exploração linguística é realizada a partir do contexto textual.

Pouquíssimas professoras enfatizaram o aspecto fonológico, apenas cinco do total das entrevistadas o mencionaram, com maior ou menor ênfase. A ênfase é, na maioria das vezes, nos aspectos gráficos. Nesse sentido, a relação entre a notação alfabética e a sua base fonológica ou é pouco explorada em contextos reflexivos, de forma sistemática e explícita, ou é abordada de forma mais tradicional. A compreensão da consciência fonológica como atividade metalinguística ainda não é tão difundida no âmbito dos discursos e práticas das professoras do universo de escolas pesquisadas. É frequente verificar a associação da consciência fonológica ao método fônico sintético, criando-se, por isso, certa resistência à possibilidade de diálogo com outras perspectivas, reproduzindo a polarização verificada no próprio campo teórico e político. Esse panorama revela a importância de fortalecer, junto ao profissional docente, as estratégias didáticas de reflexão fonológica e grafofonêmica, de modo não mecânico, em contextos reflexivos, lúdicos e letrados. ${ }^{16}$

As professoras da rede municipal de Salvador, no entanto, não parecem muito confortáveis em nenhum dos extremos dessa polarização, pois têm a dimensão de que o ensino não casual do funcionamento alfabético é necessário, mas não têm o apoio nos materiais adotados pela SMED para isso, ou têm, em alternativa, o 
método fônico, que, desconsiderando a perspectiva construtivista e sociointeracionista que vêm embasando as políticas federais e municipais, não encontra, no geral, adesão por parte delas. Das professoras entrevistadas, 16 mencionam, de algum modo, esse impasse. Fato é que os conflitos de concepção que se revelam nas políticas públicas, até então, não têm ajudado muito a sair dessa polarização. ${ }^{17}$ É interessante registrar que a participação no PNAIC foi referida nas entrevistas, a cada vez que o trabalho docente se mostrou mais bem articulado nesse sentido, condizente com pesquisas já citadas, que mostram o PNAIC como um Programa que contribuiu para conciliar a abordagem das práticas letradas com a da notação da língua.

Todas as professoras entrevistadas declararam reconhecer o valor dos jogos na aprendizagem em geral, seja por concebê-los como recurso didático, seja porque sabem que se espera que respondam positivamente à questão. Ressaltam, em geral, o seu caráter lúdico, que motiva e mobiliza o interesse das crianças, e citam, igualmente, o aprendizado de regras e as trocas entre elas. São referidos também como tendo outros objetivos, como relaxar, divertir, "distrair a mente" dos alunos ou apoiar os alunos com mais dificuldade. Em termos específicos da alfabetização, as professoras consideram os jogos, no geral, como um recurso significativo para a apropriação da língua escrita, ainda que enfatizem mais o aspecto motivador e/ou lúdico em detrimento ao didático. Mencionam a formação de sílabas e a memorização de letras, a relação entre grafema e fonema e, em menor medida, a consciência fonológica, a leitura e escrita de palavras e a ortografia. Duas professoras, no entanto, admitiram não gostar de jogos, enquanto outras declararam não conseguir ou ter muita dificuldade em inclúi-los em sua prática, devido a fatores diversos, aos quais voltaremos adiante.

Quando perguntadas sobre jogos que favorecem o processo de alfabetização, algumas professoras citaram também jogos mais gerais, bem como jogos de estratégia e de matemática, misturandose, muitas vezes, jogos de linguagem e outros. Cinco professoras do total de 25 referem a se limitar aos jogos do Nossa Rede, que são, prioritariamente, de matemática. Ainda que certa digressão seja esperada em uma entrevista semiestruturada, o fato de algumas professoras silenciarem sobre jogos de linguagem, quando a pergunta tinha esse foco, pode revelar o quanto ainda é preciso divulgar o papel do jogo na alfabetização. De fato, há professoras que conhecem bem pouco sobre o tema, referindo-se, quando provocadas, a outras estratégias ou a um repertório muito restrito de jogos, e os mais 
tradicionalmente usados, vinculados a um trabalho com aspectos mais tradicionais, como memorização de letras, de sílabas e da ordem alfabética. Por vezes a pergunta - bem específica sobre jogos para alfabetizar, gerou respostas desconfortáveis, sem a especificidade demandada, revelando quão vaga essa questão se apresenta para elas. Como na resposta da P5 (1 ${ }^{\circ}$ Ano):

\begin{abstract}
Não sei dizer que tipo de jogo favorece mais, porque precisaria, era necessário precisar isso. [...] O jogo em si ele ajuda muito porque a criança brincando, claro ela vai precisar do momento sistematizado, mas assim, a brincadeira colabora muito, a brincadeira, seja ela com o jogo didático, seja ela com é... brincadeiras infantis, vai favorecer. Então, não sei se é tão fácil dizer qual é o que mais vai colaborar na aprendizagem, não sei dizer. Eu sei dizer que trazer as brincadeiras do cotidiano para a sala de aula contribui muito, muito, até porque ele leva isso, ele vai continuar brincando, e vai fazer a ponte dessa brincadeira com o que foi visto na sala de aula, isso posso dizer que contribui muito, muito pro aprendizado dele.
\end{abstract}

Boa parte das professoras, no entanto, mostra ter conhecimento de alguns jogos e materiais estruturados que poderiam contribuir para o processo de alfabetização e dos conhecimentos linguísticos que eles podem favorecer, mas, em geral, os mais tradicionalmente usados, como alfabeto móvel, silabários; jogos de memória, dominó ou bingo de letras, sílabas e palavras; cruzadinha, caça-palavras, forca; jogos de formação de palavras, de ortografia. Poucas referiram-se a jogos e materiais com desafios de leitura, textos fatiados para ordenar, lacunados e, como já mencionado, jogos de linguagem que mobilizam a reflexão sobre os sons da língua e sua relação com a grafia.

Quanto aos jogos distribuídos pelo governo, a caixa produzida pelo CEEL/MEC foi referida por apenas 7 das 25 professoras entrevistadas, sendo que, dessas professoras, 19 participaram do PNAIC - as professoras de escolas que não participaram não citaram a caixa. Ainda assim, mesmo as que citaram referem-se muito vagamente a esses jogos, não parecendo ter muita familiaridade com eles. No geral, não conheciam seus nomes, referiam-se muito hesitantemente aos aspectos linguísticos que abordam, sendo os de rimas os mais lembrados. Apenas uma professora se referiu a esses jogos com mais propriedade. Convém lembrar que, não obstante se refiram a esses jogos, poucas professoras enfatizaram os aspectos fonológicos em seus discursos sobre as práticas alfabetizadoras. Em situações de sala de aula, não foram observados nem o uso nem a referência a esse conjunto de jogos, tampouco a situações de reflexão fonológica. Ressalta-se que, conforme levantamento dos acervos, há dessas caixas em todas as sete escolas. Em uma foram encontradas 
fechadas, em outras, trancadas em armários ou com indícios de pouco uso. Apenas em uma escola havia os jogos nas salas de aula, com indícios de uso efetivo. Nota-se, com esses dados, que a penetração dos jogos de consciência fonológica e de reflexão sobre o sistema alfabético ainda é muito pequena no universo das escolas pesquisadas, embora as professoras pareçam ansiar por estratégias produtivas para abordar os aspectos linguísticos da alfabetização. A força didática da abordagem fonológica, sobre a qual argumenta Piccoli (2015), ainda não parece ressoar contundentemente nas práticas dessas professoras.

As questões direcionadas ao âmbito do planejamento e da organização do trabalho pedagógico ratificam que, na maioria dos casos, embora refiram à importância dos jogos na alfabetização, as professoras não lançam mão deles com frequência, não os enfatizam como recurso didático de modo produtivo, e ressaltam, preferencialmente, sua natureza motivadora e não seu potencial reflexivo na aprendizagem da língua escrita - reiterando que esse uso ainda não foi, verdadeiramente, incorporado ao planejamento e às práticas. Por saberem que a expectativa é de que digam que planejam o uso de jogos, terminam por se contradizer no decorrer da entrevista, nublando-se, pelo que dizem, o que efetivamente fazem. Em relação a isso, Ferreira (2008, p. 243) argumenta: "em resultado dos programas de formação de que participam, os professores tendem a reproduzir discursos teoricamente elaborados, mas que, em vez de contribuírem para a reflexão sobre as próprias práticas, tendem a gerar efeitos de sua ocultação".

As questões que remetem ao planejamento e à organização do trabalho pedagógico incidiram sobre a relação que estabelecem entre os jogos e outras estratégias, os critérios de escolha dos jogos e de definição dos grupos para jogar, e as intervenções que realizam em situações didáticas envolvendo jogos. A maioria das entrevistadas declara inserir esses recursos em seu planejamento, mas, quando desenvolvem a questão e exemplificam suas práticas, além de não se referirem apenas a jogos de linguagem, como já discutido, frequentemente focam aspectos bem restritos. Uma professora afirmou, categoricamente, que inclui jogos cotidianamente, mas dá três exemplos, todos referentes à literatura, como a "leitura deleite" feita pela docente e a leitura ou recitação de poema ou quadrinha no final da aula, ressaltando o aspecto de jogo apenas porque cada um deverá declamá-los para ganhar prêmios.

A entrevista de cada professora - com as respostas consideradas em seu conjunto - revela que não há, na maioria das vezes, indícios de que o uso desses jogos seja, de fato, significado por estratégias didáticas 
que garantam a sua exploração como recurso didático, mediado, planejado, e muito menos com uma intencionalidade clara no âmbito dos objetivos a alcançar e em articulação com os outras estratégias didáticas. Nesse ponto é importante sublinhar que, embora os jogos sejam estruturados de modo a favorecer reflexões sobre determinado aspecto linguístico, não asseguram a aprendizagem por si mesmos. Como ressaltam Camini e Piccoli (2014), é a ação do professor, que organiza a situação e o tempo didático, as intervenções que propõe, as articulações com outros materiais e estratégias, que vão significando os materiais, efetivamente, como recursos didáticos. Trata-se do que as autoras referem como a dimensão "imaterial" que, articulada à material, potencializa o caráter pedagógico dos jogos: "O modo como cada professor cria sentido para a atividade, como a incluirá em uma rede de relação com outras atividades e dinâmicas escolares, estabelece formas particulares de relação com o que chamaremos aqui de patrimônio pedagógico imaterial do professor". (CAMINI e PICCOLI, 2014, P. 40). Mrech (apud LEAL, ALBUQUERQUE e LEITE, 2005, p. 117) ressalta, por sua vez, que "brinquedos, jogos, e materiais pedagógicos não são objetos que trazem em seu bojo um saber pronto e acabado. Ao contrário, eles são objetos que trazem um saber em potencial. Este saber potencial pode ou não ser ativado pelo aluno". Silva e Morais (2011) completam ratificando que os recursos não são, em si mesmos, condição para os sujeitos se apropriarem do conhecimento, mas meios que precisam ser, de modo intencional e deliberado, organizados pela ação docente, visando a favorecer experiências de aprendizagem. O que vai garanti-los como recurso didático é, então, ativar esses conhecimentos a partir do planejamento do professor, que organiza o trabalho pedagógico, definindo os jogos, as dinâmicas, os agrupamentos para jogar, que propõe mediações produtivas durante e após o jogo e o articula a outras estratégias diversas, seja no âmbito de sequências didáticas ou de outras modalidades que assegurem a continuidade, a diversidade e a regularidade das propostas.

Desse modo, afirmar, como afirmam as professoras entrevistadas, que os usam de forma planejada, não significa que os tomam, de fato, como recursos didáticos, nesse sentido. Em alguns relatos, o planejamento é representado como limitador da liberdade de fazerem escolhas diante de situações pontuais, como nas falas da P8 ( $1^{\circ}$ ano), referindo-se aos jogos e a sua casualidade e justificando-se: "Nem todos entram no planejamento, na minha rotina, porque nós temos que adequar os jogos à necessidade do aluno, da classe". No geral, são referidos como estratégia da qual 
lançam mão eventualmente, se a situação se apresentar, para atingir objetivos não necessariamente didáticos, revelando, nas respostas, certo desconforto com a pergunta:

[...] o jogo pra explorar a linguagem, ele vai entrar a partir da necessidade, não tem assim, tem que trabalhar jogo! Não! Ele não é uma camisa de força, tem que trabalhar. Ele vai entrar a partir da necessidade, ele vai entrar também pra, chega uma hora que eu tô vendo que os meninos estão cansados ou aquilo ali, não tá... eu não tô conseguindo fazer com que eles cheguem onde eu quero, aí eu introduzo um jogo (P5, $1^{\circ}$ ano).

São relatos que trazem certa inconsistência na compreensão da natureza do planejamento e do papel do jogo didático. É importante destacar que, para analisar essas situações, além do que efetivamente disseram, foram também considerados, na interpretação dos dados das entrevistas, suas hesitações, silêncios, desconfortos, modos de se justificar, contradições, bem como a entrevista como um todo. Como discutem Lüdke e André (2017), não basta, na entrevista, considerar o roteiro preestabelecido e as respostas verbais literais obtidas, mas prestar atenção, nessa interação, a elementos da comunicação não verbal cuja análise é relevante para compreendermos e validarmos o que foi efetivamente dito. Entrevistas com as coordenadoras também reiteram inconsistências nos argumentos de algumas professoras.

Nesse sentido, foi possível observar inconsistências e compreensões parciais sobre o potencial do jogo, e até mesmo contradições que revelam fragilidade em sua abordagem como recurso didático e a efetividade de sua presença nos planejamentos, havendo poucos registros de situações (indicadas ou observadas) que articulam as referidas dimensões material e "imaterial". Há indícios dessas inconsistências em situações de professoras que repetem o mesmo jogo muitas vezes e para todas as crianças, já enfadadas daquela proposta, sem indicação de desafios ajustados aos diferentes níveis de apropriação da língua escrita; as que afirmam não conhecer jogos de linguagem para a alfabetização, mas referirem a algum deles em outro momento, ou dizerem que não conhecem nenhum jogo, mas a escola dispor de acervos consideráveis nesse sentido; as que declaram que planejam e que incluem jogos frequentemente, mas hesitam em dizer quais e como são esses jogos e em que situação os utilizam, por vezes fechando a fala com declaração em contrário; as que indicam intervenções que consideram aspectos outros durante o jogo, que não os que favorecem as reflexões linguísticas; as que agrupam as crianças para jogar por critérios sem relação com o desenvolvimento linguístico, considerando apenas critérios aleatórios ou relativos à gestão da turma; 
as que terminam por confessar que veem potencial nos jogos apenas para as crianças "mais atrasadas", com dificuldades em aprender, por constituir em estratégia mais "flexível e livre"; as que dizem agrupar sempre "alunos mais fraquinhos" com "alunos mais fortes", para possibilitar que todos joguem, demonstrando que não planejam, de fato, os agrupamentos produtivos (nem sempre heterogêneos), nem situações desafiadoras para todas as crianças, condizentes com a perspectiva construtivista que dizem abraçar. Não houve referência, por nenhuma professora, à possibilidade de adaptação de certos jogos para desafiar crianças com diferentes domínios quanto à língua escrita, e grande parte delas relatam suas dificuldades com as intervenções durante o jogo, sejam devidas à gestão do número de jogadores, à diversidade de níveis de escrita ou à agitação. Três professoras nem vislumbram a possibilidade de reflexão linguística a partir de jogos por crianças não alfabéticas. Nas palavras de uma delas: “eu não posso colocar um jogo pra uma criança que ainda está na aquisição, no início da aquisição da escrita, da leitura" (P7, $3^{\circ}$ ano).

Nesse conjunto de situações descritas, nota-se a fragilidade quanto à proposta de jogos na alfabetização, já que, como qualquer outra estratégia didática, o jogo precisa ser planejado em função dos conteúdos a ensinar, dos objetivos a alcançar e considerando a aprendizagem de todas as crianças. Uma prática bem planejada refletiria tanto na escolha do jogo e dos agrupamentos, quanto nas intervenções a serem feitas. Apenas uma professora demonstrou desenvolver um trabalho mais consistente, planejado, articulando os jogos a outras estratégias didáticas, creditando essa forma de trabalhar às aprendizagens no contexto do PNAIC $\left(\mathrm{P} 17,1^{\circ}\right.$ ano).

O jogo não apareceu, explicitamente, nos discursos, como algo apenas para "matar o tempo" ou como um tipo de recompensa, embora apareça, nas rotinas, de forma muito assistemática e frequentemente deixado de lado em função de atividades reputadas como mais importantes. No geral, em seus relatos, as professoras articulam brincar/jogar e aprender, ainda que nem sempre consigam apresentar consistência nessa articulação. Entretanto, o equilíbrio entre função lúdica e função didática (KISHIMOTO, 2003) equilíbrio que se revela mais no modo de propor e conduzir os jogos do que nos jogos em si mesmos - nem sempre é claramente efetivo no modo como discorrem sobre suas práticas, tendendo-se a ressaltarem mais o seu caráter de brincadeira, de "novidade" para motivar, para despertar o interesse, do que, de fato, seu potencial como recurso didático. Evidentemente, o aspecto lúdico e a motivação são aspectos 
importantes, entretanto, o valor do jogo como estratégia didática se refere a sua potencialidade de gerar boas reflexões, no contexto dos objetivos do próprio jogo, em situações de interação. Nesse sentido, um dado que, embora singular, é revelador, é o de uma professora que expressou claramente a dificuldade em entender a aprendizagem articulada à brincadeira. Brincar e jogar, para ela, é diferente de aprender. Jogar seria um momento livre, sem planejamento e objetivos didáticos, seria um "momento deles", como ela definiu. Quanto a isso, no entanto, Pessoa, Lino e Silva (2015, s.p.) afirmam que:

[...] as atividades com jogos não devem ser consideradas como um processo menos sistemático por se tratar de algo que faz parte da vida das crianças e está presente nas suas práticas sociais, ao contrário, trazer para sala de aula recursos que estão na realidade das crianças é uma possibilidade lúdica de pensar sobre o SEA.

Mais rara foi a situação de focarem na função didática em detrimento da lúdica, mas, em ao menos três entrevistas, essa questão se fez presente. Duas professoras fizeram referência explícita a irem ao quadro, durante o jogo, sistematizar aspectos da escrita, como chamar a atenção para a grafia coincidente de palavras que se iniciam por mesmas sílabas ou letras, dando, inclusive, outros exemplos, fora do jogo. Trata-se de professoras que, ao discorrer sobre aspectos relacionados à intervenção durante ou depois dos jogos, relatam encaminhamentos que comprometem a dinâmica e o fluxo do jogo, ao pausá-lo para sistematizações de conteúdos postos pelas situações, em intervenções excessivamente didatizantes, comprometendo a função lúdica, no sentido dado por Kishimoto (2003).

Quanto à frequência de uso de jogos nas rotinas, a maioria das professoras indica um uso eventual e, mesmo as que indicam um uso frequente (uma, duas ou três vezes na semana), referem-se, geralmente, a jogos em geral, principalmente jogos que abordam conteúdos matemáticos ou de estratégia e brincadeiras corporais. A fase de observação das práticas e de intervenção nas salas de aula, embora em andamento e desenvolvida ainda em poucas turmas, tende a ratificar esse aspecto da inclusão assistemática e não frequente dos jogos no planejamento do trabalho pedagógico. Foram raras as situações de jogo de linguagem observadas e as crianças não pareciam ter familiaridade com a situação. Em uma turma, a reação de estranhamento das crianças à sugestão da professora de jogar certo jogo, como se fosse algo bem conhecido delas, dá indícios de que essa não era, na verdade, uma prática familiar na turma. Uma delas, com a concordância de outras, indagou, desconcertando a professora: "Pró, quando é que a gente jogou isso? Não lembro, não”. A presença da 
pesquisadora talvez tenha sido o motivo da proposta do jogo, e falas das próprias crianças no decorrer da intervenção parecem corroborar essa hipótese. ${ }^{18}$ Uma criança falou, dirigindo-se à pesquisadora: "Pró, venha mais vezes para a gente poder jogar mais!", ao que outras emendaram: "A gente gostou de aprender brincando", "Foi muito legal descobrir as rimas". Nessa turma, de $1^{\circ}$ ano, as propostas de leitura eram, geralmente, de sílabas soltas e formação de palavras aleatórias.

Muitas professoras, ainda que defendam a importância dos jogos na alfabetização e seu planejamento articulado aos objetivos didáticos, diante da questão sobre a frequência de uso de jogos na rotina, se veem numa situação de contradição e lamentam não se dedicarem mais a esse aspecto, explicitando dificuldades legítimas em relação a essa baixa frequência, como as muitas exigências da rede ou do próprio trabalho docente. Apenas no caso de duas professoras há indícios de que os jogos são, de fato, frequentes na rotina das turmas. As justificativas dadas pelas professoras para o pouco uso de jogos e outros materiais semelhantes contribuem para entendermos mais esse panorama, revelando tanto dificuldades reais relativas aos desafios da docência, quanto "desculpas" para certa acomodação nesse sentido. Como justificativa para esse pouco uso ou quanto às dificuldades encontradas para incluí-los na prática, os motivos alegados foram de diversas naturezas, revelando desde aspectos estruturais, como falta de tempo, de espaço e de jogos, e a quantidade de alunos na turma, quanto formativos e pedagógicos, tais que a falta de formação e o comportamento dos alunos, referido como "bagunça" ou "agitação" por algumas professoras.

Para responder sobre esse ponto, ora falavam de si mesmas, suas próprias justificativas para a baixa frequência de uso de jogos em suas turmas, ora respondiam da perspectiva das dificuldades que atribuem em geral a esse pouco uso. Algumas respondiam fazendo um mea culpa, outras responsabilizavam as questões estruturais, comportamentais e/ ou formativas, por vezes não se implicando quanto a essa situação, apesar da resistência pessoal expressa em outros momentos da entrevista. Os aspectos mais citados para essa baixa frequência de uso foram a falta de formação, de tempo, de jogos, o número elevado de alunos, seus diferentes níveis em relação à apropriação da escrita, bem como o comportamento das crianças nas situações de jogo. A questão era aberta, não consistindo de alternativas para indicar. Algumas indicaram apenas a justificativa principal, outras citaram mais aspectos. O quadro a seguir sistematiza as ocorrências das menções a esses aspectos mais referidos pelas professoras, registrando o número de menções em relação ao total de 25 professoras: 
QUADRO 1. Justificativas para a baixa presença de uso de jogo como recurso didático

\begin{tabular}{|l|c|}
\hline \multicolumn{1}{|c|}{ Aspectos mais referidos } & Ocorrências \\
\hline $\begin{array}{l}\text { Falta de tempo devido às altas demandas cotidianas da escola, da rede, ou a carga } \\
\text { horária dupla de trabalho em sala de aula }\end{array}$ & 11 \\
\hline $\begin{array}{l}\text { Falta de experiência/formação para a pesquisa, uso e/ou confecção de jogos; falta } \\
\text { de domínio quanto ao uso de jogos na alfabetização }\end{array}$ & 9 \\
\hline $\begin{array}{l}\text { A agitação ou dispersão dos alunos durante o jogo, incluindo a dificuldade de lidar } \\
\text { com regras e a competitividade }\end{array}$ & 8 \\
\hline $\begin{array}{l}\text { Falta ou escassez de jogos em geral ou de jogos que não contemplam as } \\
\text { dificuldades das crianças }\end{array}$ & 6 \\
\hline $\begin{array}{l}\text { Número elevado de alunos na turma } \\
\text { A heterogeneidade da turma, com níveis muito diversos de domínio da leitura } \\
\text { e escrita }\end{array}$ & 6 \\
\hline Falta de tempo pedagógico pela necessidade de cumprir os programas da rede & 5 \\
\hline
\end{tabular}

Como se pode concluir pelos dados, quanto ao tempo e às muitas demandas, foram 16 referências (itens $a$. e $g$.), sendo que o tempo delas, de planejamento, seleção e/ou confecção de materiais, foi o mais citado (11 menções). Entretanto, também foi aludido o tempo pedagógico (cinco menções), que não comportaria tal estratégia nas rotinas, devido às demandas dos programas da rede. Nesse sentido, foi citado, em especial, o Nossa Rede. Embora a referência explícita a esse tempo pedagógico se limite a cinco menções, outras professoras também referiram a esse aspecto como desafio, mas não como elemento impeditivo. Em uma escola, particularmente, a queixa quanto a essas demandas foi unânime, uma das três professoras entrevistadas apresentou como justificativa, além das demandas, a própria acomodação com o programa, e a falta de tempo de planejar e de "encaixar" jogos na rotina. Outra enfatizou o "engessamento" do material desse programa - ou do modo como elas são cobradas a utilizá-lo - e a falta de propostas de jogos no caderno de língua portuguesa. Em outras escolas esse aspecto também foi pontualmente mencionado por uma ou outra professora. Dentre as falas que remetem a programas que precisam cumprir, uma professora de $1^{\circ}$ ano diz:

Eu utilizo muito pouco essa questão dos jogos. Eu acho que o jogo tem uma importância fundamental, mesmo, na prática da alfabetização. Mas como a gente já recebe esses programas prontos, pra gente dar conta né? [...] A gente trabalha agora 
com o Nossa Rede, junto, auxiliando com o livro didático, então nesse material já vem algumas atividades... Às vezes não dá tempo da gente pensar em questão de jogos pra atender esses recursos, pra atender esse material. (P1, $1^{\circ}$ ano).

Embora seja preciso considerar que há, também, alguma acomodação ao que vem "pronto" - ainda que justificada pelos enormes desafios da docência - coloca-se aqui a questão do apagamento das vozes das escolas, das professoras e da autoria de suas práticas, a partir do que é predefinido por esses sistemas estruturados. Vozes que são roubadas por uma lógica de imposição quanto ao que e como ensinar e avaliar nas redes públicas de ensino, sob o poder crescente do "mercadores da educação", como define Morais (2018), referindose aos empresários da educação envolvidos em ações junto ao poder público. Embora o Nossa Rede, apresentado com a retórica da "construção coletiva", marque sua especificidade quanto à identidade e ao protagonismo da rede em sua elaboração, suas contradições apareceram, revelando-se, conforme discute Souza (2018), como um sistema estruturado e monitorado, de caráter gerencial, que, segundo resultados de sua pesquisa, limita a autonomia das escolas e dos(as) docentes. Cabe aqui discutir sobre a ideia da "escola atarefada", mencionada por Correia (apud FERREIRA, 2008), que geraria baixa reflexão sobre o que deve ser efetivamente mudado, bem como inconformidade com essa condição. Ferreira (2008) denuncia essa versão gerencial da escola, com o professor submetido aos sistemas monitorados de ensino e às tantas demandas relativas a documentos institucionais, que tornam as "boas práticas" menos importantes do que a burocracia e o controle. $\mathrm{O}$ autor argumenta que tal visão tem produzido efeitos no nível das subjetividades dos professores, sendo um deles "gerar ou acentuar o sentimento de que as mudanças na esfera da ação pedagógica lhes são exteriores". (FERREIRA, 2008, p. 248) Quanto a isso Morais (2018) completa:

\footnotetext{
Com seus "sistemas de ensino", "apostilados" e "programas de aceleração", os empresários da educação têm conseguido que redes municipais ou estaduais inteiras usem os mesmos "pacotes" padronizados, que desconsideram, por completo, a diversidade dos aprendizes e desrespeitam os conhecimentos e as trajetórias dos docentes, querendo que estes, ordeira e docilmente, sigam o que os autores dos pacotes impuseram. (MORAIS, 2018, p. 860)
}

É com formação qualificada de professores que é preciso se contrapor à gestão desses sistemas, que têm base numa racionalidade técnica e instrumental, tipo de racionalidade que, como afirma Giroux (1997), compromete a autonomia das escolas, a responsabilidade ativa dos professores quanto ao que e como ensinam, reduzindo-os a 
executores de prescrições predefinidas, e limitando o processo educativo à aplicação de pacotes e transmissão de conteúdos estruturados. Quanto a essas questões, as professoras entrevistadas parecem fazer coro, embora também seja frequente se acomodarem a essa condição.

Referindo-se, justamente, à falta de formação específica para questões didáticas e/ou, em especial, para o uso de jogos na alfabetização, as nove professoras que mencionaram esse aspecto citam a formação inicial e continuada, indicando tanto a falta de conhecimento de jogos disponíveis e possíveis nessa área, quanto para articulá-los à prática pedagógica. Algumas referiram-se à realização de oficinas como estratégia formativa, tanto para compreenderem os aspectos linguísticos que os jogos abordam e seus usos como estratégia didática, quanto para aprender a confeccioná-los, tendo mediação nessa produção. A formação foi mencionada, de forma assertiva, por nove professoras, embora outras também tenham se referido à falta de conhecimento didático para uma prática qualificada na alfabetização.

Uma professora associa jogos a um ensino construtivista e declara que "o que funciona mesmo é o método tradicional". Embora esse relato destoe dos demais (ao menos referente ao que é explicitado nos discursos), as falas de professoras cuja prática é mais "tradicional" e que vão na direção da resistência a essas "inovações" ou, ainda, as que julgam que já o fazem suficientemente só por disponibilizarem jogos em algum momento assistemático do tempo pedagógico, podem indicar, no entanto, posição semelhante, mesmo que não a assumam de forma explícita. Referindo-se ao "isso eu já faço", declaração frequente quanto a propostas que venham a balançar as práticas docentes, Camini e Piccoli (2014, p. 40) argumentam que há docentes que "[...] estão sempre à espreita desses elementos conhecidos para justificar os muros que erguem em torno de suas práticas pedagógicas". As autoras completam, sublinhando que elas tentam, com isso, se tornar " [...] imunes a apelos que possam tirar suas práticas de bases confortáveis, geralmente estabelecidas em longo período, tentando sobreviver em uma profissão tão exigente como a docência." (CAMINI e PICCOLI, 2014, p. 40) Em duas escolas, as coordenadoras pedagógicas criticaram a resistência das professoras a repensarem suas estratégias, a ampliarem e inovarem suas práticas, alegando que não vão "mexer no que está dando certo" - trata-se de escolas em que as práticas alfabetizadoras se revelaram pouco afetadas pelos avanços do campo da alfabetização e do discurso pedagógico nas últimas décadas, embora se mesclem, também, a esse discurso pedagógico, já que crenças, valores e saberes docentes vão além de 
avanços e inovações nas instâncias das tematizações e normatizações, conforme será discutido adiante.

Quanto ao comportamento dos alunos durante o jogo, indicado por oito professoras, inclui-se a agitação por ser um momento mais dinâmico, e a dificuldade das crianças em lidarem com regras e a competitividade, que criam, segundo as docentes, situações que comprometem a gestão da turma. O descuido com os materiais também foi citado. Uma delas diz:

\footnotetext{
Umas das questões que nós professores [...] pensamos muito, duas vezes, em trabalhar com jogos é a bagunça na sala de aula. A bagunça, o barulho, a indisciplina. A depender da turma, trabalhar com jogos estimula muito palavras torpes, muitas crianças não aceitam, não têm aquela ideia de regra; existe regra para o desenvolvimento dos jogos, mas muitas crianças não aceitam, aí começam a xingar, começam a bater. ( $\mathrm{P} 8,1^{\circ}$ ano)
}

Jogar, sem dúvida, provoca certo "alvoroço" na sala, por envolver situações mais dinâmicas, competição, cooperação, autonomia na gestão do jogo, postura ativa, regras e a manipulação de materiais concretos. Certamente, aprender a obedecer as regras, a competir, a perder e ganhar, a agir coletivamente em prol de um resultado, a cuidar dos materiais, implica muito investimento pedagógico, pois, como ressaltam diversos autores, o jogo envolve também o desenvolvimento social das crianças. Muitas professoras declaram que o jogo dá trabalho, por esses motivos todos, mas, em alguns depoimentos, tal argumento aparece como justificativa para sua exclusão na rotina. Embora apenas uma professora tenha explicitado essa questão nesses termos tão claros, nota-se, pelas falas em geral, que esse "dar trabalho" tem um peso na baixa frequência de jogos no planejamento e nas rotinas das turmas.

Outros aspectos foram citados por um número menor de professoras, como o número elevado de alunos, a heterogeneidade da turma, com níveis muito diversos de domínio da leitura e escrita, e a escassez de jogos - o que não se sustenta, considerando que as que o citaram não usam os que a escola tem disponíveis. Além disso, um planejamento bem articulado, quando se tem familiaridade com os jogos e seus desafios linguísticos, pode contornar a questão do número de alunos e da heterogeneidade da turma, favorecendo o engajamento de todos e propondo desafios ajustados às diferentes possibilidades de reflexão linguística.

Diante dessas dificuldades e justificativas apontadas, o aspecto mais referido como elemento que pode contribuir para ampliar o uso de jogos nas práticas alfabetizadoras foi, justamente, a necessidade da 
formação dos professores, visto que muitos não tiveram, na graduação, um componente curricular que abordasse estratégias didáticas para alfabetizar, nem uma formação continuada específica voltada à prática com jogos e com o lúdico. Sobre a formação inicial uma professora diz:

Eu acho que, primeiro, a faculdade pode, na disciplina de matemática, na disciplina de alfabetização [...] incentivar os futuros professores. Porque no meu tempo, não tinha, sabe? Eu não fui orientada para. Até quando eu fiz o meu curso, não lembro desse incentivo para trabalhar os jogos, a gente conheceu algumas coisas, mas não tinha esse incentivo. (P 15, $2^{\circ}$ ano)

Por fim, é importante considerar que, conforme apontam Albuquerque, Morais e Ferreira (2008, p. 255), na ação docente, o professor combina elementos diversos, das teorias estudadas na formação - inicial ou continuada - e das orientações oficiais, misturando-as com suas próprias "“apropriações', 'interpretações', mudanças, reparos e readaptações" nas situações práticas, "fabricando o cotidiano", nos termos que argumenta Certeau (1998), citado por esses autores. Dessas combinações de saberes, tanto podem resultar boas práticas, que consideram diversos aspectos importantes na apropriação da linguagem escrita, suas diversas facetas, ajustando lacunas dos programas adotados nas redes, quanto podem gerar apropriações inadequadas, fugindo de mudanças efetivas de práticas já questionadas, ou se acomodando a esses programas. Observou-se essa "fabricação" no contexto das escolas do universo da pesquisa. As professoras tateiam buscando conciliar perspectivas, hesitam, buscam validação quanto aos ajustes que vão fazendo e clamam por um apoio teórico-metodológico para fundamentar práticas voltadas para o ensino do sistema alfabético, nubladas pelas descontinuidades político-pedagógicas decorrentes das opções do governo municipal. Sem esse apoio, e considerando a tensão entre o que propõem as diferentes esferas do poder público quanto às políticas de alfabetização, essas práticas, quanto à faceta linguística, terminam por se desenvolver ainda ancoradas em metodologias mecanicistas, em práticas "bricoladas" ao letramento e/ou justapostas ao que entendem como sendo validado pela proposta construtivista, que é refletir sobre a notação apenas em situações de leitura e escrita de textos, de modo mais casual do que intencionalmente e explicitamente planejado.

\section{CONSIDERACְÕES FINAIS}

Incluir jogos e outros materiais semelhantes na prática pedagógica parece ser, de fato, um desafio que requer disposição e 
conhecimento, como bem mostra a quantidade de ocorrências da expressão "falta de" indicadas pelas falas registradas. Mas, como declarou uma professora, referindo-se aos desafios, não podemos, simplesmente, "varrer para debaixo do tapete", mas assumi-los, buscando, também, lutar pela melhoria das condições que dificultam o trabalho, em vez de paralisar diante dos inúmeros entraves. Outra professora afirmou, com muita convicção, que acredita que a grande maioria dos professores já utilizam jogos no processo de alfabetização. Não é o que a pesquisa mostra e, ainda que estejamos considerando apenas 25 professoras de 7 escolas, de uma rede, esses resultados dão indícios de que muito ainda é preciso avançar. A pesquisa aponta um uso muito limitado de jogos, a pouca exploração dos aspectos fonológicos na alfabetização, encaminhamentos ainda muito mecânicos no ensino do funcionamento alfabético do sistema de escrita e baixa incidência de planejamento efetivo de jogos de linguagem como estratégia didática produtiva, seja para se apropriar de novos conhecimentos, seja para consolidar aprendizagens já realizadas a partir de outras estratégias. Foi, no geral, mais referido como recurso para mobilizar a motivação, memorizar de forma mais leve, ou para ajudar crianças que têm mais dificuldade na aprendizagem da escrita.

No processo de levantamento de dados, foi notório o discurso mais coeso, coletivo e produtivo das profissionais de algumas escolas, que parecem ter se beneficiado mais com a formação do PNAIC. Nessas escolas, os discursos que circulam são mais marcados pela perspectiva trazida por esse programa de que a linguagem é multifacetada e que, ao lado das práticas de leitura e escrita, do letramento, é preciso também abordar a faceta linguística de forma explícita e sistemática, ensino que não se opõe, necessariamente, à ideia de um sujeito ativo, que constrói conhecimentos nas interações com a linguagem e a cultura escrita. De qualquer modo, mesmo nessas escolas, sobressaem os aspectos gráficos aos fonológicos, e ainda precisa ser ampliada a ideia de que as crianças pensam também sobre unidades sublexicais da língua, numa atividade de natureza metacognitiva e não como repetição e treinamento mecânicos.

Observou-se, por outro lado, professoras que nem conseguem vislumbrar jogos que explorariam aspectos importantes para essa apropriação na alfabetização inicial, salvo jogos de letras e sílabas. Foi mais frequente remeterem os jogos a crianças que já têm algum domínio do sistema de escrita. Como discute Araujo (2017, 2018), jogos fonológicos e materiais estruturados a partir da tradição oral, envolvendo rimas, sílabas iniciais e fonemas vocálicos, sem e com 
presença da escrita, são, no entanto, muito produtivos para os que ainda não consideram o princípio alfabético, mesmo para os que ainda não fonetizam a escrita - e jogos desse tipo estão presentes na caixa do CEEL, de que todas as escolas dispõem, conforme foi constatado na análise dos acervos.

Ou seja, parece que as estratégias para abordar essa dimensão metalinguística em contextos lúdicos e letrados precisam ser ainda consolidadas, para que a abordagem da faceta linguística não se dê por justaposição de práticas letradas com metodologias mecânicas de ensino da notação alfabética - sejam elas as do passado ou as ditas "novidades" requentadas, como o método fônico, reiteradamente propalado como alternativa para os problemas da alfabetização no país. Experiências com o PNAIC em outros Estados, bem como a de Lagoa Santa, coordenada por Magda Soares, indicam práticas mais consistentes nesse sentido (cf. MORAIS, 2018).

O fato de os aspectos metalinguísticos e o ensino explícito do sistema de escrita serem enfatizados por campos de conhecimento que, muitas vezes, rivalizam com a perspectiva construtivista adotada na rede, dificulta a sua assunção como um referencial produtivo para as práticas alfabetizadoras, apesar de haver uma necessidade, por vezes velada, de que sejam validadas as práticas docentes que focam nos aspectos linguísticos da alfabetização. Por falta de conhecimentos mais atualizados sobre perspectivas de abordagem sistemática da língua em seus aspectos fonológicos e notacionais, ou por falta de segurança em assumi-los face aos discursos pedagógicos validados pela escola ou pelos programas adotados pela rede municipal, as professoras terminam se apoiando em metodologias que conhecem, mesmo em métodos já amplamente questionados no campo da alfabetização. Diz uma professora: "eu acreditava muito no construtivismo [...], comecei utilizando muito o construtivismo. Mas depois eu percebi que as crianças precisavam de algo que facilitasse mais essa questão do soletrar mesmo..." (P7, $3^{\circ}$ ano). A polarização de concepções ressoa nos discursos e práticas das professoras, contribuindo, ao lado dos outros desafios apontados, para o fato de não recorrerem, na grande maioria das vezes, a materiais disponíveis na escola, embora declarem sentir falta de estratégias para alfabetizar.

Esses dados, embora parciais, indicam o quanto ainda é necessário, no contexto da formação docente, inicial ou continuada, investirmos na organização do trabalho pedagógico e nas estratégias didáticas de alfabetização, e reafirmar o valor dos jogos de linguagem como recurso produtivo. Ainda que desenvolvida numa rede específica, 
e considerando a voz de um número reduzido de professoras, a pesquisa, a partir desses dados, talvez possa retratar também outros contextos, mais amplos, em decorrência dos conflitos e polarizações que se estabelecem, nacionalmente, nas instâncias das concepções teóricas e das políticas públicas de alfabetização. Ampliar a pesquisa para outros contextos pode ser produtivo para conhecermos mais sobre discursos e práticas nas redes públicas de ensino e mobilizar saberes e fazeres quanto ao ensino da língua escrita nos anos iniciais. Tanto contextos de formação continuada, que considerem os saberes da prática e as representações dos professores, quanto na formação inicial, há muito a ser feito para transformar positivamente as práticas alfabetizadoras, assegurando, ao mesmo tempo a qualificação e a autonomia docente.

Após considerar todas as categorias de análise das entrevistas, e da conclusão da fase de observação, intervenção e avaliação da intervenção, teremos uma visada mais assertiva sobre a problemática em questão, ampliando-se as articulações entre a produção de conhecimento na Universidade e a produção de conhecimento nas escolas. Ao final da pesquisa, esses resultados serão a base para defendermos a constituição de laboratórios de alfabetização como ação permanente na formação inicial de professores, no sentido de enfatizar a dimensão material da ação docente, ampliando-se as relações entre teoria e prática, entre concepções e didáticas, entre conteúdos, objetivos e estratégias didáticas, entre dimensão material e "imaterial", entre jogo e aprendizagem.

Esperamos, por fim, que a pesquisa e o Laboratório que dará continuidade, na FACED/UFBA, às ações nela operadas, por ter seu foco na faceta linguística, não deem aval a práticas que validem exclusivamente essa faceta e cujas metodologias girem em torno de meras técnicas a serem aplicadas. Jogos não são exercícios técnicos disfarçados de brincadeira, nem um recurso que vale por si só. Pretendemos, ao contrário, contribuir para colocar foco nessa faceta, em outras bases, "reinventar a alfabetização", mas nos mantendo firmes na relação com a língua viva e com os sujeitos infantis em suas interações sociais mediadas pela linguagem. Por outro lado, enfatizando a dimensão material da ação docente, pretende-se, igualmente, afirmar a autonomia didática do professor para avaliar, selecionar e até mesmo produzir materiais, assegurando a autoria de sua prática, na contramão do apagamento das vozes dos professores, operado por sistemas de ensino padronizados, reducionistas e controladores, que pretendem homogeneizar toda a rede e, que, ainda que de forma velada, sustenta-se numa suposta incapacidade intelectual dos professores, conforme sugere Giroux (1997). 
Em tempos de sistemas estruturados impostos aos docentes, de anúncios de políticas públicas federais que desqualificam os avanços no campo e enfatizam a consciência fonêmica como ponto de partida e pré-requisito para a alfabetização inicial, é fundamental a assunção de estratégias didático-pedagógicas produtivas e mais amplas que abranjam a dimensão fonológica da alfabetização e o ensino explícito do nosso sistema de escrita, para fazer face ao engodo de que a única alternativa a uma didática que desconsidera a sistematicidade desses aspectos seja a suposta "milagrosa" abordagem fônica, em sua vertente sintética, como panaceia para todas as questões da alfabetização no país. ${ }^{19} \mathrm{O}$ campo da alfabetização, como campo científico e didático, precisa se posicionar fora dos sectarismos, estabelecendo diálogos mais frutíferos e divergências mais respeitosas, e se aproximar das práticas dos professores, de suas representações e de suas apropriações singulares das discussões teórico-metodológicas do campo. Ouvir as vozes das professoras e professores pode ser também um caminho produtivo para encontrarmos o tom, pois é na prática pedagógica que docentes precisam dar conta dos inúmeros desafios de um objeto cultural e de conhecimento, por natureza, multifacetado.

\section{REFERÊNCIAS}

ALBUQUERQUE, E. B. C. de; MORAIS, A. G. de; FERREIRA, A. T. B. As práticas cotidianas de alfabetização: o que fazem as professoras?. Rev. Bras. Educ. [online]. 2008, vol.13, n.38, pp. 252-264. Disponível em: http://www.scielo.br/pdf/rbedu/v13n38/05.pdf. Acesso em: 24 out. 2017.

ARAUJO, L. C. de. A dimensão material da ação e formação de alfabetizadores. Revista Contemporânea de Educação, v. 13, n. 27, maio/ago. 2018, p. 311-329.

- Jogos e materiais pedagógicos na alfabetização e a dimensão material da ação docente. In: III Congresso Brasileiro de Alfabetização - CONBALF, 2017, Vitória. Anais do III Congresso Brasileiro de Alfabetização: diálogos sobre alfabetização. Vitória: UFES, 2017. p. 390-399.

BEZERRA, V. S. S. B. Jogos de Análise Fonológica: Alguns Percursos na Interação de Duplas de Crianças. Dissertação (Mestrado em Educação), Universidade Federal de Pernambuco, Recife; UFPE, 2008. Disponível em: https://repositorio.ufpe.br/ handle/123456789/4347. Acesso em: 18 jun. 2018.

BORTONI-RICARDO, S. M. O Professor pesquisador: introdução à pesquisa qualitativa. São Paulo: Parábola, 2008.

BRANDÃO, A. C. P. A.; FERREIRA, A. T. B.; ALBUQUERQUE, E. B. C. de; LEAL, T. F. Jogos de Alfabetização (org.). Jogos de Alfabetização: manual didático. Ministério da Educação/CEEL/UFPE. Pernambuco: Editora Universitária, 2009. 
CAMINI, P.; PICCOLI, L. O patrimônio pedagógico imaterial na alfabetização. Pátio: Ensino Fundamental, v. 71, p. 40-43, 2014.

CARDOSO-MARTINS, C. Consciência fonológica e aprendizagem da leitura e da escrita. Cadernos De Pesquisa. São Paulo, v. 76, 1991. p. 41-49.

CERTEAU, M. de. A invenção do cotidiano: 1. Artes de fazer. Petrópolis: Vozes, 1998.

DOHME, V. Atividades lúdicas na educação: o caminho de tijolos amarelos do aprendizado. Petrópolis, RJ: Vozes, 2008.

FERREIRA, F. I. Reformas educativas, formação e subjetividades dos professores. Revista Brasileira de Educação, v. 13 n. 38 maio/ago. 2008, p. 239-409.

GOMBERT, J. É. Le Développement métalinguistique. Paris : PUF, 1990.

GIROUX. H. A. Os professores como intelectuais. Porto Alegre: Artmed, 1997.

GONTIJO, C. M. M. Alfabetização: políticas mundiais e movimentos nacionais. Campinas/ SP: Autores Associados, 2014.

IBIAPINA, I. M. L. de M. Pesquisa Colaborativa: investigação, formação e produção de conhecimentos. Brasília: Liber Livros, 2008.

KISHIMOTO, T. M. O jogo e a educação infantil. In: KISHIMOTO, T. M. (org.). Jogo, brinquedo, brincadeira e a educação. Cortez: São Paulo, 2003, p. 13-43.

LEAL, T. F.; ALBUQUERQUE, E. B. C. de; LEITE, T. M. R. Jogos: alternativas didáticas para brincar alfabetizando (ou alfabetizar brincando?). In: MORAIS, A. G. de; ALBUQUERQUE, E. B. C. de; LEAL, T. F. (org.). Alfabetização: apropriação do sistema de escrita alfabética. Belo Horizonte: Autêntica, 2005, p. 111-131.

LÜDKE, M.; ANDRÉ, M. E. D. A. Pesquisa em educação: abordagens qualitativas. São Paulo: EPU, 2017.

MACEDO, L. de; PETTY, A. L. S; PASSOS, N. C. Aprender com jogos e situações problema. Porto Alegre: Artmed, 2000.

MACHADO; M. G. K.; SPESSATTO, M. B. Ressignificando a docência: as mudanças na prática cotidiana asseguradas pelas formações do PNAIC. In: Alfabetização na perspectiva do letramento: letras e números nas práticas sociais. Florianópolis/SC: UFSC/CED/NUP, 2016, p. 67-76.

MORAIS, A. G. de; ALBUQUERQUE, E. B. C. de; LEAL. T. F. (org.). Alfabetização: apropriação do sistema de escrita alfabética. Belo Horizonte: Autêntica, 2005.

MORAIS, A. G. de. Concepções e metodologias de alfabetização: Por que é preciso ir além da discussão sobre velhos métodos? Brasília, DF: Secretaria de Educação Básica, 2006, s/p. (Trabalho apresentado no Seminário Alfabetização e Letramento em Debate). Disponível em: http://portal.mec.gov.br/seb/arquivos/pdf/Ensfund/alf_moarisconcpmetodalf.pdf. Acesso em: 24 nov. 2018. 
MORAIS, A. G. de. Sistema de escrita alfabética. São Paulo: Melhoramentos, 2012. (Coleção Como eu Ensino).

MORAIS, A. G. de. A republicana proposta curricular de Língua Portuguesa que Magda Soares vem construindo com os educadores de Lagoa Santa - MG: coerência e inovação. Práxis Educativa, Ponta Grossa, v. 13, n. 3, p. 857-877, set./dez. 2018 Disponível em: http://www.revistas2.uepg.br/index.php/praxiseducativa. Acesso em: 21/11/2018.

MORTATTI, M. do R. L. Os sentidos da alfabetização: São Paulo/1876-1994. São Paulo: UNESP: CONPED, 2000.

MORTATTI, M. do R. L. Alfabetização no Brasil: conjecturas sobre as relações entre políticas públicas e seus sujeitos privados. Revista Brasileira de Educação, v. 15 n. 44 maio/ago. p. 329-410, 2010.

PESSOA, A. C. R. G.; LINO, L. de G.; SILVA, C. E. da. O uso de jogos no ciclo de alfabetização: estratégias desenvolvidas por docentes em processo de formação. In: Anais II Congresso Brasileiro de Alfabetização: políticas públicas de alfabetização, Recife, 2015, s.p. Disponível em: http://abalf.org.br/wp-content/uploads/2015/02/O-USO-DEJOGOS-NO-CICLO-DE-ALFABETIZAÇÃO-ESTRATÉGIAS-DESENVOLVIDASPOR-DOCENTES-EM-PROCESSO-DE-FO.pdf. Acesso em: 25 jun. 2018.

PIAGET, J. A formação do símbolo na criança. Rio de Janeiro: Jahar, 1975.

PIAGET, J. ONascimento da inteligência na criança. Rio de Janeiro: Zahar, 1978.

PIAGET, J. Psicologia e pedagogia. Rio de Janeiro: Forense Universitária, 1969/1976.

PICCOLI, L. Como formar um professor alfabetizador no curso de pedagogia? Discussões sobre a formação inicial nas universidades federais da região sul do Brasil. In: Revista Brasileira de Alfabetização - ABAlf. Vitória/ES. v. 1, n. 1, jan./jun. 2015, p. 132-154. Disponível em: http://abalf.org.br/revistaeletronica/index.php/rabalf/article/view/42/33. Acesso em: 10/08/2018.

SILVA, A.; MORAIS, A. G. de; Brincando e aprendendo: os jogos com palavras no processo de alfabetização.In: LEAL, T. F.; SILVA, A.da (org.). Recursos didáticos e ensino da língua portuguesa: computadores, livros ...e muito mais. Curitiba: Editora CRV, 2011, p. 13-26.

SNOWLING, M. J.; HULME, C. A ciência da leitura. Porto Alegre: Penso, 2013.

SOARES, M. A reinvenção da alfabetização. Revista Presença Pedagógica, v.9 n.52, jul./ ago. 2003.

SOARES, M. Letramento e alfabetização: as muitas facetas. Revista Brasileira de Educação. Jan /Fev / Mar / Abr 2004, n² 25, p. 5-17. Disponível em: http:/ /www.scielo.br/ pdf/rbedu/n25/n25a01.pdf. Acesso em: 10 jun. 2018.

SOARES, M. Alfabetização: a questão dos métodos. São Paulo: Contexto, 2016.

SOUZA, D. S. de. Nós na Rede - formação continuada na perspectiva do Coletivo de Coordenadores Pedagógicos de Salvador: tensões, desafios e potenciais. Tese de Doutorado (Educação). Universidade Federal da Bahia, 2018. 
SZYMANSKI, H. (org.). A entrevista na pesquisa em educação: a prática reflexiva. Brasília: Líber Livro, 2002.

VERCELLI, L. de C. A.; JULIOTI, S. A prática pedagógica alfabetizadora após formação pelo Pacto Nacional de Alfabetização na Idade Certa (PNAIC). Crítica Educativa, v. 3, n. 1, p. 34-49, jan./jun. 2017. Disponível em: http://www.criticaeducativa.ufscar.br/index.php/ criticaeducativa/article/view/133/245. Acesso em: 30 jan. 2019.

VYGOTSKY, L. S. A formação social da mente: O Desenvolvimento dos Processos Psicológicos Superiores. São Paulo: Martins Fontes, 1984.

WEISZ, T. Didática da leitura e da escrita: questões polêmicas. Pátio - Revista Pedagógica, Porto Alegre: Artmed, n. 28, nov./dez., 2003 - jan. 2004.

\section{NOTAS}

1 Ressalta-se que essa perspectiva embasou o Pacto Nacional de Alfabetização na Idade Certa (PNAIC), política pública que, a despeito de possíveis limitações e diversidade de implementações em diferentes Estados, alcançou resultados positivos, apontados por pesquisas diversas (PESSOA, LINO e SILVA, 2015; MACHADO e SPESSATTO, 2016; VERCELLI e JULIOTI, 2017).

2 Pesquisa financiada pelo PROPESQ - Programa de Apoio a Jovens Doutores Universidade Federal da Bahia (UFBA)/Ministério da Ciência, Tecnologia, Inovações e Comunicações (MCTIC).

3 Optamos pela marcação do gênero feminino para nos referir às docentes em consideração ao fato de serem maioria nessa etapa da educação e na pesquisa.

4 Sobre o laboratório e a discussão sobre a dimensão material da ação e formação docentes em torno dessa ação, ver Araujo (2018).

5 De 2017 a 2019 a pesquisa contou com a participação de cinco bolsistas, três no Ensino Fundamental e duas na Educação Infantil: bolsistas PIBIC (UFBA, CNPQ e FAPESB) e bolsista PROPESQ.

6 As oficinas constituem atividade de extensão articulada à pesquisa, voltadas a profissionais das escolas, estudantes e público interessado. Os recursos compõem o acervo do LAP, cujas ações de pesquisa, produção e validação de materiais e o planejamento de situações didáticas, constituem a vertente da pesquisa voltada para a formação inicial de professores.

7 Para conhecer os objetivos específicos das outras etapas da pesquisa, ver Araujo (2017).

8 A fase de observação, com duração variável em um período mínimo de um mês, estava em andamento no momento da consolidação dos dados para o presente artigo, tendo sido finalizada e analisada em apenas duas escolas, em duas turmas de $1^{\circ}$ ano.

9 Os métodos e instrumentos utilizados obedeceram aos procedimentos éticos estabelecidos para a pesquisa científica em Ciências Humanas (CEP/CONEP -Parecer $n^{\circ}:$ 2.931.413).

10 A didática de cunho construtivista (a didatização da teoria construtivista), fortemente presente no discurso pedagógico, tendo inspirações na corrente da whole language, ainda que não ignore esse aspecto, terminou por divulgar a ideia de que o sistema grafofônico não 
precisa ser objeto de ensino direto e explícito, sua aprendizagem decorreria de forma natural nas interações com a escrita e a partir da organização didática de situações de reflexão mais assistemáticas (cf. SOARES, 2004).

11 Estamos cientes de que o jogo didático é, por vezes, visto negativamente, por ter objetivos fora do próprio jogo. Registra-se, porém, que há nesse argumento, muitas vezes, um preconceito com o que seja "didático".

12 Na continuidade dos Parâmetros Curriculares Nacionais (PCN), o PROFA se constituiu em um programa de formação continuada de professores alfabetizadores, sob supervisão de Telma Weisz, lançado no final de 2000 pela Secretaria de Educação Fundamental do MEC, e tendo seu apoio até 2002.

13 Ao Pró-Letramento seguiu-se o PNAIC, a partir de 2012/2013, como política do MEC, envolvendo de forma mais ampla as Universidades na formação.

14 Um conjunto de jogos do projeto TRILHAS, do Instituto Natura, foi também distribuído pelo MEC em diversas escolas de capitais e municípios prioritários, em 2013, envolvendo ações de instâncias federais, estaduais e municipais.

15 Os recursos didáticos que constituem o acervo do LAP vêm sendo produzidos desde o início dos anos 2000, inicialmente para uso em disciplinas de uma faculdade particular, e em oficinas de produção de material no contexto de Estágio Docente na UFBA e de um programa de formação docente na mesma instituição. Esse acervo vem sendo divulgado no blog: http://oficinasdealfabetizacao.blogspot.com/.

16 A consciência grafofonêmica remete à consciência fonêmica em sua relação com a grafia (SOARES, 2016).

17 Importante ressaltar que essas disputas, no âmbito do poder público municipal de Salvador, não são de caráter teórico-metodológico, revelando, mais precisamente, um jogo de interesses políticos e editoriais.

18 A fase de intervenção foi, até o momento, realizada em duas turmas de $1^{\circ}$ ano, em escolas diferentes.

19 Consideramos o que se anuncia a partir do Decreto 9.765, de 11 de abril de 2019, que institui a Política Nacional de Alfabetização (PNA), e do Caderno lançado em 15 de agosto de 2019, que aponta a abordagem fônica, referendada pela ciência cognitiva, como referência única para a alfabetização na política do MEC.

Submetido: 26/02/2019

Aprovado: 10/08/2019

Contato:

Prof $^{\text {a }}$. Liane Castro de Araujo

Faculdade de Educação - Universidade Federal da Bahia (UFBA) Avenida Reitor Miguel Calmon, s/n - Campus Canela

Salvador $|\mathrm{BA}|$ Brasil

CEP 40.110-100 